\title{
Bartonella henselae Antibodies in Serum and Oral Fluid Specimens from Cats
}

\author{
Alejandra Álvarez-Fernández ${ }^{1}$, Marta Baxarias ${ }^{1} \mathbb{D}$, David Prandi ${ }^{1} \mathbb{D}$, Edward B. Breitschwerdt ${ }^{2} \mathbb{D}$ and \\ Laia Solano-Gallego $1, *$ (D)
}

1 Departament de Medicina i Cirurgia Animals, Facultat de Veterinària, Universitat Autònoma de Barcelona, Bellaterra, 08193 Barcelona, Spain; Alejandra.alvarez@uab.cat (A.Á.-F.); Marta.baxarias@uab.cat (M.B.); david.prandi@uab.cat (D.P.)

2 Intracellular Pathogens Research Laboratory, Department of Clinical Sciences, Comparative Medicine Institute, College of Veterinary Medicine, North Carolina State University (NCSU), Raleigh, NC 27607, USA; ebbreits@ncsu.edu

* Correspondence: laia.solano@uab.cat

check for updates

Citation: Álvarez-Fernández, A.; Baxarias, M.; Prandi, D.;

Breitschwerdt, E.B.; Solano-Gallego,

L. Bartonella henselae Antibodies in Serum and Oral Fluid Specimens from Cats. Pathogens 2021, 10, 329. https://doi.org/10.3390/ pathogens10030329

Academic Editor: Valentina

Virginia Ebani

Received: 24 February 2021

Accepted: 7 March 2021

Published: 11 March 2021

Publisher's Note: MDPI stays neutral with regard to jurisdictional claims in published maps and institutional affiliations.

Copyright: (c) 2021 by the authors. Licensee MDPI, Basel, Switzerland. This article is an open access article distributed under the terms and conditions of the Creative Commons Attribution (CC BY) license (https:// creativecommons.org/licenses/by/ $4.0 /)$.

\begin{abstract}
Cats are the primary reservoir host for Bartonella henselae (B. henselae), an etiological agent of human bartonellosis, including cat scratch disease. Although Bartonella DNA has been amplified from salivary swabs from cats, dogs and humans, we are not aware of studies investigating Bartonella antibodies in oral fluid (OF). Using inhouse and commercial immunofluorescence antibody assays (IFA), the objective of this study was to detect and compare antibodies against $B$. henselae in paired $\mathrm{OF}$ and serum specimens from cats. Specimens were collected from shelter and client-owned cats. For serum specimens, $B$. henselae seroreactivity was $78 \%$ for both the inhouse and commercial IFA assays and $56.8 \%$ for OF specimens. Comparing serum and OF specimens, there was moderate Kappa agreement (Cohen's $\mathrm{k}=0.434$ ) for detection of $B$. henselae antibodies. Oral fluid antibodies were more likely measurable in cats with high $B$. henselae serum antibody titers when compared with low antibody titers. In conclusion, $B$. henselae OF IFA antibody measurements were less sensitive compared to serum IFA measurements of $\geq 1: 64$. Oral fluid antibodies were detected more often in cats with high $B$. henselae serum antibody titers. Therefore, OF antibodies, detectable by IFA, is of limited utility for epidemiological or diagnostic testing in cats.
\end{abstract}

Keywords: bartonellosis; feline; serology; immunofluorescence antibody assay; oral fluid

\section{Introduction}

Cats are the primary reservoir for $B$. henselae, the etiological agent of human cat scratch disease, and a major cause of bartonellosis across animal species [1,2]. Bartonella henselae is considered a stealth pathogen, particularly in dogs and humans, where published data is expanding the spectrum of clinical manifestations that have been historically associated with this infection [3].

For clinicians and researchers, documentation of Bartonella infection in most animal species remains a challenge due to the lack of sensitive and/or specific testing modalities. Testing limitations apply to diagnostic assays used to evaluate cats, dogs and humans for indirect (antibody) or direct (culture, antigen, DNA) evidence of Bartonella spp. infections [4-6]. Despite a wide variety of currently available commercial and research testing modalities, a negative serological or direct detection test result does not guarantee the absence of this stealth pathogen [7-9]. The combination of a thorough clinical data analysis, including age, sex, animal and arthropod vector exposure history, physical examination findings, ancillary laboratory testing, in conjunction with indirect and direct diagnostic microbiological techniques is the most effective strategy for the diagnosis of Bartonella spp. infections $[6,10,11]$. 
The immunofluorescence antibody assay (IFA) is the most widely employed serological technique to measure Bartonella spp. IgM or IgG antibodies in patient sera [12]; however, Enzyme-Linked Immunosorbent Assays (ELISA) [13] and Western immunoblot assays are also commercially available [14]. Seronegativity is an important limitation during early acute infection and in a subset of animal and human patients during longstanding bloodstream infections $[15,16]$. In the context of direct detection, PCR is the most frequently used molecular assay to detect the presence of Bartonella spp. DNA in patient specimens, including whole blood, fresh or frozen tissue, lymph node aspirates and saliva $[17,18]$. Combining enrichment culture prior to PCR testing is a diagnostic strategy developed to optimize the documentation of "active" infection [19]. Moreover, low and potentially relapsing bacteremia rates may represent limiting factors for the sensitivity of PCR and enrichment blood culture/PCR techniques. Noninvasive specimens, such as saliva, have been analyzed using PCR to detect Bartonella spp. DNA in cats [20,21]. Oral fluids (OF) include whole saliva, fractionated saliva, gingival crevicular fluid, and dentinal tubular fluid [22]. Therefore, oral fluid samples include not only saliva but also crevicular and dentinal tubular fluids, which we refer to collectively as OF in this study. To our knowledge, OF has not been used for the detection of antibodies against $B$. henselae antigens in cats. Salivary IgG originates via gingival transudation from the capillary network below the oral mucosa [23]. Documentation of salivary IgG offers clinicians and researchers the possibility to obtain an alternative diagnostic specimen for the detection of Bartonella-specific antibodies. Saliva has been used previously as the diagnostic specimen for detecting antibodies against feline immunodeficiency virus (FIV) and feline leukemia virus (FeLV) in cats $[24,25]$. In general, it is substantially easier, less stressful, and less invasive to collect saliva than a blood sample from feline patients. In addition, it does not need much expertise. However, both venipuncture and saliva collection could be a challenge in some cats without sedation, particularly in the feral cat populations targeted in seroepidemiological studies [26]. The aim of this study was to detect and compare antibodies against B. henselae IFA antigens in paired serum and OF specimens from cats.

\section{Results}

\subsection{Description of the Study Cats}

All the cats were European domestic short hair. Sixty-seven of 118 (56.8\%) were female and $51(43.2 \%)$ were male cats. Their ages ranged from 4 months to 7 years, with a median age of 1.7 years. For statistical analyses, cats $\leq 2$ years old were considered young cats and $>2$ years old were considered old cats. One hundred and sixteen of $118(98.3 \%)$ were sexually intact at the time of entry into the study. Shelter and client-owned cats comprised $55.1 \%(65 / 118)$ and $44.9 \%(53 / 118)$, of the study population, respectively. Owned cats ranged in age from 5 months to 7 years, with a median age of 2.4 years. Shelter cats ranged in age from 4 month to 5 years, with a median age of 1.2 years. Shelter cats were more likely to be young cats $(73.8 \%)$ when compared with old cats (37.7\%) (Chi square test: $\mathrm{X} 2=15.59$, $\mathrm{df}=1, p<0.001)$. History of tick and flea infestations were reported in $56.8 \%(67 / 118)$ of the cats, while $19.5 \%(23 / 118)$ were flea-infested at the time of sampling (21 shelter cats and two client-owned cats). Shelter cats were more likely to have a history of tick and/or flea infestation $(100 \%)$, when compared with client-owned cats (3.8\%) (Fisher exact test, $p<0.001)$. Routine treatment with ectoparasiticides was only reported for 25 client-owned cats, $21.2 \%(25 / 118)$ of total cats. One hundred cats $(84.7 \%)$ were assessed as clinically healthy, whereas $18(15.3 \%)$ cats had clinical signs with gingivitis being the most frequent clinical sign found in nine sick cats (50\%).

\subsection{Inhouse Versus Commercial IFA Testing of Cat Sera}

Considering antibody titers $\geq 1: 64,78 \%(92 / 118)$ cats were $B$. henselae seroreactive when tested using both the inhouse and commercial IFA assays (Figure 1). The B. henselae serum IFA geometric mean titer was 1:2088 with minimum and maximum titers of 1:64 and 
1:16,384, respectively. Bartonella henselae antibody titers ranged from 1:64 to 1:512 in 35.9\% $(33 / 92)$ and $>512$ in $64.1 \%(59 / 92)$ of the seroreactive cats.

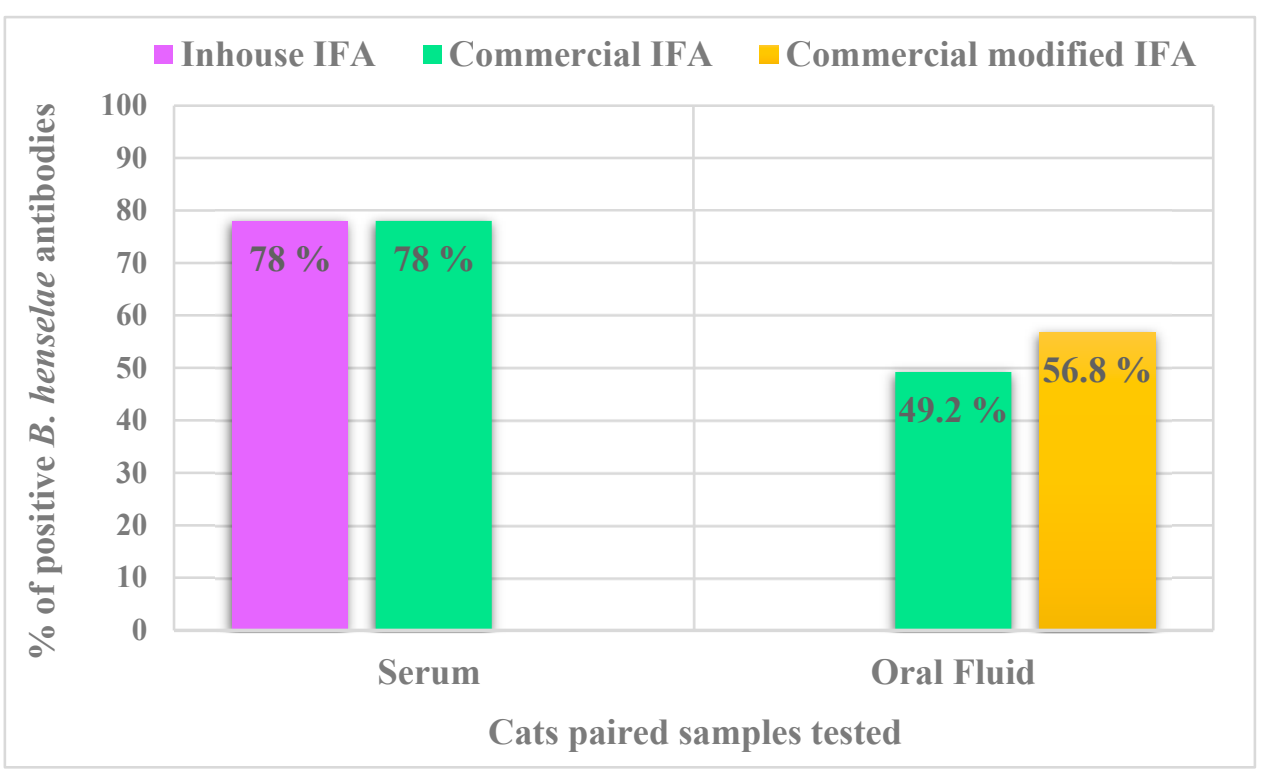

Figure 1. Comparison of the proportion of IFA positive results in serum and OF specimens for the detection of antibodies against B. henselae antigens. Abbreviations: IFA, immunofluorescence antibody assay.

When considering antibody titers $\geq 1: 64$ for the 118 cats in this study, Kappa agreement, was almost perfect when comparing the inhouse IFA and the commercial IFA kit (Cohen's $\mathrm{k}=1 ; 95 \%$ confident interval) (Table 1 ).

Table 1. Comparison of IFA agreement in serum and OF samples.

\begin{tabular}{ccc}
\hline Test Pair & $\kappa \pm \mathrm{SE}$ & $\boldsymbol{\kappa}^{\text {Interpretation }}{ }^{\mathbf{a}}$ \\
\hline $\begin{array}{c}\text { Inhouse IFA serum versus } \\
\text { commercial IFA serum }\end{array}$ & $1 \pm 0.000$ & Almost perfect agreement \\
$\begin{array}{c}\text { Commercial IFA serum versus } \\
\text { commercial IFA OF }\end{array}$ & $0.429 \pm 0.068$ & Moderate agreement \\
$\begin{array}{c}\text { Commercial IFA serum versus } \\
\text { commercial modified IFA OF }\end{array}$ & $0.541 \pm 0.072$ & Moderate agreement
\end{tabular}

a The interpretation for each $\mathrm{K}$ value is shown in the final column according to the following scale: $\leq 0$, no agreement; 0.01-0.20, none to slight; 0.21-0.40, fair; 0.41-0.60, moderate; 0.61-0.80, substantial; and 0.81-1.00, almost perfect agreement. Abbreviations: IFA, immunofluorescence antibody assay; OF, oral fluid; $k$, Cohen's kappa value; SE, standard error.

There was moderate Kappa agreement (Kappa $=0.587 ; 95 \%$ confidence interval) when comparing negative, low positive and high positive inhouse IFA antibody titers with the fluorescence intensity for the commercial IFA (Figure 2). Based upon comparative analysis, shelter cats were more likely to have serum $B$. henselae antibodies $(100 \%)$ when compared with client-owned cats $(50.9 \%)$ (Fisher exact test, $p<0.001)$ (Table 2). Furthermore, shelter cats were more likely to have high serum antibody titers (>1:512.) against $B$. henselae $(69.3 \%)$ when compared with client-owned cats $(26.4 \%)$ (Chi square test: $\mathrm{X} 2=42.99, \mathrm{df}=2$, $p<0.001)$. When age was considered, cats $\leq 2$ years were more likely to be $B$. henselae seroreactive (98.5\%) than cats $>2$ years $(50 \%)$ of age (Fisher's exact test: $p=0.001)$. 

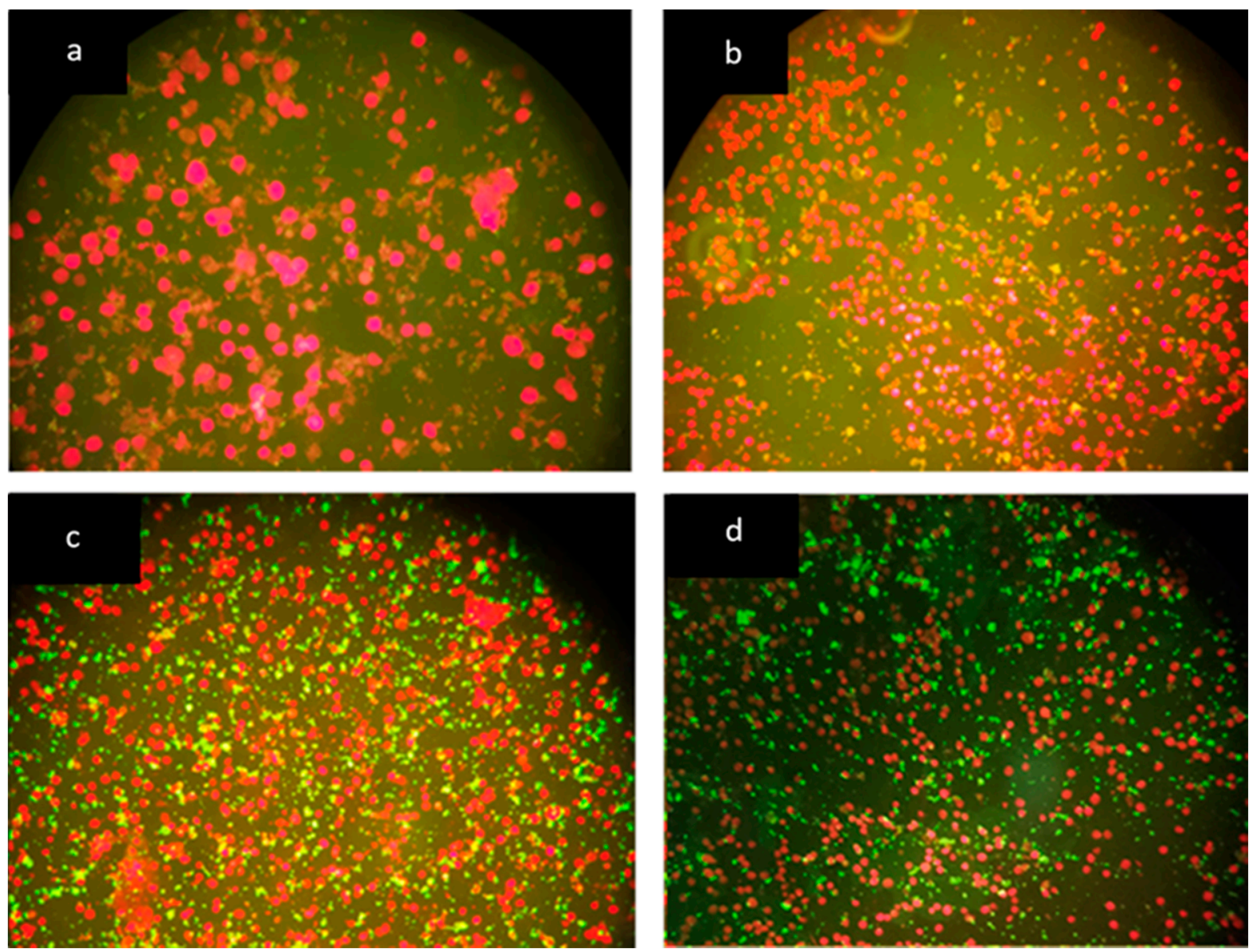

Figure 2. Visual subjective criteria for classification of $B$. henselae antibody concentration according to fluorescence intensity. (a) Negative, cells stain in red $(400 \times)$, (b) negative/nonspecific fluorescence $(200 \times)$, cells stain in red, (c) low positive $(200 \times)$, and $(\mathbf{d})$ high positive $(200 \times)$. Bartonella henselae organism stain apple green in panels $(\mathbf{c}, \mathbf{d})$.

Table 2. Comparison of demographic and clinical variables among cats based upon the proportion of commercial IFA $B$. henselae seroreactors in serum and OF.

\begin{tabular}{|c|c|c|c|c|c|c|c|c|c|c|c|c|c|c|c|}
\hline \multirow{3}{*}{ Specimens } & \multicolumn{15}{|c|}{ Variables } \\
\hline & \multicolumn{3}{|c|}{ Lifestyle } & \multicolumn{3}{|c|}{ Age } & \multicolumn{3}{|c|}{ Sex } & \multicolumn{3}{|c|}{ Clinical Status } & \multicolumn{3}{|c|}{ Ectoparasites Presence } \\
\hline & $\begin{array}{c}\text { Client } \\
\text { Client-Owned } \\
(n=53)\end{array}$ & $\begin{array}{l}\text { Shelter } \\
(n=65)\end{array}$ & $p$ Value & $\begin{array}{l}\leq 2 \text { Years } \\
(n=68)\end{array}$ & $\begin{array}{l}>2 \text { Years } \\
(n=50)\end{array}$ & $p$ Value & $\begin{array}{l}\text { Females } \\
(n=67)\end{array}$ & $\begin{array}{c}\text { Males } \\
(n=51)\end{array}$ & $p$ Value & $\begin{array}{l}\text { Healthy } \\
(n=100)\end{array}$ & $\begin{array}{c}\text { Sick } \\
(n=18)\end{array}$ & $p$ Value & $\begin{array}{c}\text { Yes } \\
(n=23)\end{array}$ & $\begin{array}{c}\text { No } \\
(n=95)\end{array}$ & $p$ Value \\
\hline Serum & $50.9 \%$ & $100 \%$ & $<0.001$ * & $98.5 \%$ & $50 \%$ & $<0.001$ * & $79.1 \%$ & $76.5 \%$ & $0.732 *$ & $75 \%$ & $94.4 \%$ & 0.118 ** & $100 \%$ & $72.6 \%$ & $0.004^{* *}$ \\
\hline $\mathrm{OF}$ & $20.7 \%$ & $72.3 \%$ & $<0.001$ * & $64.7 \%$ & $28 \%$ & $<0.001$ * & $52.2 \%$ & $45.1 \%$ & 0.442 * & $45 \%$ & $72.2 \%$ & 0.086 * & $78.3 \%$ & $42.1 \%$ & 0.002 ** \\
\hline
\end{tabular}

IFA: immunofluorescence antibody assay. $n$ : number. OF: oral fluid. ${ }^{*}$ Chi-square test; ${ }^{* *}$ Fisher's exact test; a significant association was deduced when $p<0.05$.

\subsection{Commercial IFA in Serum and OF Samples}

Using the commercial IFA, 78\% (92/118) of cats were B. henselae seroreactive. All cats $B$. henselae seronegative in both IFA assays were also negative in the OF IFA assay $(26 / 118)$. When seroreactivity results were categorized using specific fluorescence intensity as the criteria described in Figure 2, 22\% (26/118) of cats were seronegative, 15.3\% (18/118) were low positives and $62.7 \%(74 / 118)$ were high positives. Only $49.2 \%(58 / 118)$ of cat OF samples were $B$. henselae antibody positive prior to the sample concentration step. When comparing serum and OF samples, there was moderate Kappa agreement for detection of B. henselae antibodies, using the commercial IFA assay (Cohen's $\mathrm{k}=0.429 ; 95 \%$ confidence interval) (Table 1). Considering the end point inhouse IFA titer results, OF samples were more likely to be positive in cats with high B. henselae serum antibody titers (>1:512) $(77.2 \%)$ when compared with low antibody titers $(\leq 1: 512)(22.8 \%)$ (Fisher's exact test: $\mathrm{P}=0.001)$. 
Comparisons between commercial serum and OF IFA results, when categorized as low positive or high positive based upon inhouse IFA antibody titers are provided in Table 3. Oral fluid antibodies were also more frequently found in young cats ( $\leq 2$ years old) $(64.7 \%)$, compared to older cats ( $>2$ years old) $(28 \%)$ (Chi square test: $\mathrm{X} 2=18.87, \mathrm{df}=1, p<0.001)$. The statistical comparison of the proportions of positive results based on clinical parameters in both serum and OF samples are listed in Table 2. Serum and OF antibody titers did not differ between sick cats with gingivitis and the rest of the sick and healthy cats. However, all sick cats with gingivitis were seroreactive and seven of nine cats with gingivitis were OF positives. Six gingivitis cats had serum antibody titers $\geq 1: 512$.

Table 3. Comparison between commercial B. henselae IFA results in serum and OF, when categorized as low positive and high positive to the serum inhouse antibody IFA titer results.

\begin{tabular}{ccccc}
\hline & \multicolumn{5}{c}{ Number of Positive Cats } \\
\hline \multirow{2}{*}{$\begin{array}{c}\text { Serum Inhouse IFA } \\
\text { Antibody Titers }\end{array}$} & \multicolumn{4}{c}{ Commercial IFA } \\
\cline { 2 - 5 } & Low Positive & High Positive & Low Positive & High Positive \\
\hline $\begin{array}{c}\text { Low positive } \\
1: 64-1: 512 \\
(n=33)\end{array}$ & 11 & 22 & 8 & 5 \\
\hline $\begin{array}{c}\text { High positive }>512 \\
(n=59)\end{array}$ & 8 & 51 & 19 & 26 \\
\hline Total $(n=92)$ & 19 & 73 & 27 \\
\hline
\end{tabular}

* Total OF results including commercial modified IFA. Abbreviations: IFA, immunofluorescence antibody assay, n, number; OF, oral fluid.

\subsection{Modified Commercial IFA Testing of OF Specimens}

Fifty-two of 60 available B. henselae antibody OF negative samples and 10 antibody OF positive samples were retested using the modified IFA. All previously positive IFA OF samples remained $B$. henselae positive, 9 of 52 previously IFA negative samples became IFA positive. In total $56.8 \%(67 / 118)$ of OF samples were $B$. henselae antibody reactive when tested by both IFA assays. Of the 92 B. henselae seroreactors, 67 (72.8\%) were OF antibody positive. Comparison of the proportions of positive results in serum and OF using the two IFA assays are shown in Figure 1. There was moderate Kappa agreement for detection of $B$. henselae antibodies, when comparing total results obtained in serum and OF samples using the commercial (not modified) and modified IFA assays (Table 1, Cohen's $\mathrm{k}=0.541 ; 95 \%$ confidence interval).

\section{Discussion}

Although several studies have documented the presence of Bartonella spp. DNA in oral samples obtained from cats $[20,27,28]$, to the best of our knowledge, studies reporting the presence of $B$. henselae antibodies in OF samples have not been published. Among the 92 B. henselae seroreactors in this study, only 67 (72.8\%) were also OF antibody positive. In agreement with our findings, a previous study determined that total IgG was lower in oral samples when compared with serum samples [29]. To collect the OF samples, we used cotton swabs soaked with hypertonic NaCL $7.5 \%$ to increase oral transudation and salivation. Therefore, we obtained a higher volume of OF; however, it is possible that the OF antibody concentration was diluted by the saline soaking of the swabs. In a study investigating total IgG using ELISA, higher OF immunoglobulin concentrations were obtained using unstimulated samples (dry swabs) [29]. Unfortunately, it was not possible in the present study to collect OF samples with dry swabs, likely due to an inhibitory effect of the anesthetic drugs on the production of OF. In order to increase IFA OF sensitivity, we used the commercial IFA with modifications, which resulted in 9 out of 52 negative samples being positive. It is possible that detection of $B$. henselae antibodies in OF specimens could 
be improved by concentrating saliva samples and thereby increasing the overall and $B$. henselae-specific antibody concentrations. Consistent with this concept, a recent study focused on the IgG purification of human saliva in order to achieve a high similarity of $\operatorname{IgG}$ antibody profiles from blood and saliva for diagnostic testing purposes [30].

In the present study, there were no statistical differences in B. henselae seroreactivity among cats with gingivitis compared to the rest of all cats, which is in agreement with previous studies [31,32]. However, all sick cats with gingivostomatitis in this study were $B$. henselae seroreactive and the majority were OF positive as well. High antibody titers were reported in a previous study that established a relationship between oral lesions and B. henselae and Bartonella clarridgeiae antibodies [21]. The results of this study differ from studies involving FIV seropositive cats [26] and cats with chronic gingivostomatitis [29]. FIV seropositive cats had increased salivary IgG levels, but this result was partly attributable to the presence of oral inflammatory lesions as suggested by the higher ratios of salivary IgG than serum IgG in both FIV seronegative and seropositive cats with oral lesions compared to cats without oral lesions [26]. Similarly, cats with chronic gingivostomatitis had significantly higher salivary IgM and IgG, but significantly lower salivary IgA concentrations than healthy cats [33]. In contrast, higher salivary IgA and lower IgM and IgG were reported in healthy cats using ELISA and single radial immunodiffusion (SRID) assays [29]. In addition to the clinical status (healthy vs. sick for gingivostomatitis) of the cat, variable results in detection of antibodies may be due to the use of different diagnostic techniques, IFA and Western blot had also been used as immunoglobulin diagnostic techniques for OF [24]. In dogs, similar concentrations of anti-Leishmania IgG2 antibodies were found in serum and saliva measured by time-resolved immunofluorometric assays (TR-IFMAs), likely due to the high sensitivity of this assay [34].

Because of many factors, IFA assays could be considered subjective techniques, including the skills and experience of the technologist in results interpretation, antibody cross-reactions, and antigen sources used. These and other factors influence IFA sensitivity and specificity. In this study, we found identical seroreactivity results using inhouse and commercial B. henselae IFA assays. Furthermore, there was moderate agreement when comparing antibody intensity categories in the commercial assay to inhouse IFA antibody titers. Although it is necessary to develop more studies focused on the determination and measuring of antibodies in OF or saliva as a diagnostic technique, recently published OF optimization studies performed in other infections [24,29] could indicate that $B$. henselae OF could provide an efficient alternative to serum. Despite the low sensitivity of OF when compared with serum, OF noninvasive specimens could be an important resource for antibody detection procedures in cats and other animals from whom blood collection is challenging. In the present study, swabs were maintained in the mouth for 3-4 min but it is likely that with less time similar results will be obtained. Therefore, further OF collection and sample processing studies are needed to enhance the sensitivity of $\mathrm{OF}$ for Bartonella spp. antibody detection diagnosis in cats.

In this study, the very high $B$. henselae seroprevalence indicates that infection with Bartonella is common among shelter cats with high ectoparasite exposure in areas around Barcelona. Others studies involving cats from Spain have reported Bartonella spp. seroprevalence rates of 23.8\% (Madrid) [35], 29.6\% (Catalonia) [36], 35.3\% (Catalonia) [37], and 71.4\% (Catalonia and Mallorca Island) [38]. Seroprevalence differences between Spanish studies likely relate to the source of the cats, with higher risk being associated with stray and shelter cats because of extensive flea exposure and lack of prophylaxis. This study is in agreement with evolving evidence that cats living in the Mediterranean region have higher Bartonella spp. prevalence than others areas in Spain and Europe [4].

\section{Materials and Methods}

4.1. Cats

One hundred and eighteen cats from Barcelona province (Spain) were enrolled into the study between 2017 and 2019. A clinical questionnaire was completed for each cat 
including information about age, breed, sex, shelter/client-owned, health status (sick versus healthy), presence of fleas and / or ticks, or bites and the use of acaricide products. For all cats, a complete physical examination was performed by a veterinarian. In most cases $(n=110)$, blood specimens were obtained under general anesthesia during a routine neutering procedure.

\subsection{Serum Specimens}

For each cat at the time of enrollment, peripheral blood was collected by jugular or cephalic venipuncture, with 4-6 mL placed in serum tubes containing a clot accelerator and granule serum separator (Aquisel, Barcelona, Spain). These samples were centrifuged at $790 \times g$ for 10 min (Heraeus Labofuge 400R, Thermo Fisher Scientific, Waltham, MA, USA) to obtain the serum that was stored at $-80{ }^{\circ} \mathrm{C}$ until used.

\subsection{Oral Fluid Specimens}

To obtain the OF, a swab (Ecouvillon PP, Dominique Dutscher, Bernolsheim, France) was soaked with hypertonic NaCL 7.5\%. (B. Braun Melsungen AG, Melsungen, Germany) to obtain oral transudation and salivation. The swap was placed into the cat's mouth between the gum and the inner mucosa of the upper or lower lip. To obtain the OF sample for antibody testing, the swab was maintained in that position for 3-4 min, after which the swab head was placed in an Eppendorf tube and centrifuged at $16000 \times g$ for $10 \mathrm{~min}$ (Eppendorf Centrifuge 5418, Merck KGaA, Darmstadt, Germany). OF samples were stored at $-80^{\circ} \mathrm{C}$ until tested.

\subsection{Bartonella henselae Inhouse IFA Serological Testing}

Initially, the 118 cat sera were tested at North Carolina State University, Intracellular Pathogens Research Laboratory using a previously inhouse B. henselae IFA assay for end point antibody titration [15,38] with some modifications and validated in dogs [7]. Briefly, to obtain antigens for IFA testing, B. henselae SA2+ (feline origin Missy 95 FO-099), was passed from agar grown cultures into DH82 (a continuous canine histiocytic cell line) cultures. Heavily infected cell cultures were spotted onto 30-well Teflon-coated slides (Cel-Line/Thermo Scientific), air-dried, acetone-fixed, and stored frozen. Serum samples were diluted in phosphate buffered saline (PBS) solution containing 1\% normal goat serum, 0.05\% Tween-20 and 0.5\% powdered nonfat dry milk (BioRad, Hercules, CA, USA) to block non-specific antigen binding sites. Patient sera were further tested with 2-fold dilutions out to a final dilution of $1: 16,384$ and $10 \mu \mathrm{L}$ of every serum dilution was applied per well. The slides were incubated for $30 \mathrm{~min}$ at $37^{\circ} \mathrm{C}$ and washed with PBS under moderate agitation for another $30 \mathrm{~min}$. Once slides were dry, $10 \mu \mathrm{L}$ of fluorescein-conjugated goat IgG anti-cat (MP biomedicals, Irvine, CA, USA) at dilution of 1:100 was added into each well. The slides were incubated for another $30 \mathrm{~min}$ at $37^{\circ} \mathrm{C}$ in the dark to protect the photosensitive conjugate. The washing procedure described above was repeated adding a few drops of Tween 20. After the last washing procedure, some drops of mounting medium (Vectashield, Burlingame, CA, USA) were added on the cover slips. The slides were evaluated using a fluorescence microscope (OPTIKA Fluo B-383, OptikaItaly, Ponteranica, Italy) at $200 \times$ and $400 \times$ magnification and each well was compared to the fluorescence pattern seen in the positive and negative controls. To avoid confusion with possible nonspecific binding found at low dilutions, a cutoff of 1:64 was selected as a seroreactive antibody titer [38]. Cats were considered seronegative at titers $<1: 64$. For statistical comparisons, cats were categorized as low antibody positive for titers between 1:64 and 1:512 and high antibody positive for titers $>1: 512$. Experimental infection studies in cats have documented that the geometric mean of maximum antibody titer peak was $\geq 1: 512[15,39]$. Moreover, previous studies in dogs and humans have classified antibody titers of $\geq 1: 512$ as high positives $[40,41]$. 


\subsection{Bartonella henselae Commercial IFA Paired Serological and OF Testing}

An indirect immunofluorescence assay (MegaFLUO B. henselae, Diagnostik Megacor, Hörbranz, Austria) for the detection of IgG antibody against $B$. henselae antigens was performed on paired sera and OF samples. Immunofluorescence antibody assay was performed for all cats included in this study at the Autonomous University of Barcelona. The serum samples were diluted to 1:64 with PBS while OF samples were not diluted. Twenty microliters of every paired sample, diluted serum and not diluted OF from the same cat, were applied in different wells in the same slide. The slides were incubated for $30 \mathrm{~min}$ at $37^{\circ} \mathrm{C}$. After that, a washing procedure was performed. The slides were washed twice with PBS for $5 \mathrm{~min}$ and once with distilled water. After the washing procedure described, $15 \mu \mathrm{L}$ of FLUO FITC anti-cat IgG conjugate was added into each well. The slides were incubated for another $30 \mathrm{~min}$ at $37^{\circ} \mathrm{C}$ in the dark to protect the photosensitive conjugate. The washing procedure described above was repeated. After the second washing procedure, some drops of mounting medium were added on the cover slips. The slides were evaluated using a fluorescence microscope (Leica DM6000 B; Leica Microsystems, Wetzlar, Germany) at 200× and $400 \times$ magnification and each well was compared to the fluorescence pattern seen in the positive and negative controls. All samples were examined by two different investigators to avoid observer error. Serum samples that were not fluorescent at a 1:64 titer were considered seronegative according to the manufacturers' instructions and as previously described $[42,43]$. To compare OF versus serum antibody reactivity, the intensity of the specific organism (B. henselae) fluorescence observed was used as subjective criteria for classifying antibody concentration into negative, low positive and high positive (Figure 2). Due to economic restrictions, endpoint antibody titration was not performed with $B$. henselae commercial IFA whereas serum antibody titration was determined by the inhouse IFA.

\subsection{Modified B. henselae Commercial IFA OF Testing}

For the 52 of the 60 OF samples that were B. henselae-antibody negative, a modified IFA assay was performed. There was inadequate volume to retest eight OF negative samples. The modified IFA procedure was performed for 10 previously OF positive samples and 52 OF negative samples. The objective of this modification was to determine if $B$. henselae $\mathrm{OF}$ antibodies could be detected by adding double the volume of the OF. Thus the modified commercial IFA used $40 \mu \mathrm{L}$ of OF instead $20 \mu \mathrm{L}$. Indirect immunofluorescence assay (MegaFLUO B. henselae, Diagnostik Megacor, Hörbranz, Austria) for the detection of specific IgG antibody against $B$. henselae antigens was performed by adding a second OF sample incubation step. Following the protocol described above, after the first washing procedure, another $20 \mu \mathrm{L}$ of nondiluted OF sample was applied in the same well of first incubation, after which the slide was incubated again for $30 \mathrm{~min}$ at $37^{\circ} \mathrm{C}$. The rest of the commercial IFA protocol was followed without modification and the results were read as described above using classification criteria shown in Figure 2.

\subsection{Statistical Analysis}

The cumulative data collected from each cat, as well as the B. henselae antibody detection, in paired serum and OF samples were evaluated statistically. Frequency analysis for age, sex, stray/client-owned, ectoparasites, healthy status and the different IFA assays results was assessed. Comparative analysis of categorical data was performed by using chi-square test or Fisher's exact test. The kappa (k) statistic was used to assess the degree of (interrater) agreement between end point inhouse IFA results and commercial IFA results classified using the subjective criteria described in Figure 2. Kappa was used also to assess the degree of agreement between commercial IFA used to test serum and OF samples. The following interpretation of the $\mathrm{k}$ statistic was: $\mathrm{k}<0$ poor, $\mathrm{k}=0-0.2$ slight, $\mathrm{k}=0.21-0.4$ fair, $\mathrm{k}=0.41-0.6$ moderate, $\mathrm{k}=0.61-0.8$ substantial, $\mathrm{k}=0.81-1$ almost perfect agreement. A significant association was deduced when $p<0.05$. The statistical analysis was performed using the R program i386 version 3.6.1 ( $R$ Development Core Team) ( $R$ Foundation for Statistical Computing, Vienna, Austria) and the Deducer R program version 1.7-16 (De- 
ducer: a data analysis GUI for R) (R Foundation for Statistical Computing company, Vienna, Austria) for Windows software.

\title{
5. Conclusions
}

In conclusion, $\mathrm{OF}$ antibodies were more likely to be detected in cats with high $B$. henselae serum antibody titers. When compared with sera in this study, measuring $B$. henselae OF antibodies by IFA testing was less sensitive. Therefore, without further successful optimization of Bartonella spp. antibody detection, OF specimens do not appear to be an adequately sensitive epidemiological or diagnostic assay for testing cats. In the context of test reproducibility, the inhouse and commercial IFA assays generated identical seroreactive and seronegative results for the 118 cats in this study.

Author Contributions: Conceptualization, A.Á.-F. and L.S.-G.; methodology, A.Á.-F. and D.P.; formal analysis, A.Á.-F., L.S.-G. and M.B.; investigation, A.Á.-F., D.P. and L.S.-G.; resources, L.S.-G. and E.B.B.; data curation, A.Á.-F.; writing-original draft preparation, A.Á.-F.; writing-review and editing, L.S.-G. and E.B.B.; visualization, A.Á.-F.; supervision, L.S.-G. and E.B.B.; project administration, L.S.-G.; funding acquisition, L.S.-G. All authors have read and agreed to the published version of the manuscript.

Funding: This research was funded by Bayer Animal Health/Elanco.

Institutional Review Board Statement: The study was conducted according to the guidelines of the Declaration of Helsinki, ethical review and approval were waived for this study by UAB ethical committee, due to noninvasive procedures and the use of residual specimens.

Informed Consent Statement: A signed consent form was obtained from the owner or the person in charge of the cat(s).

Data Availability Statement: The data presented in this study are available on request from the corresponding author.

Acknowledgments: The authors thank all veterinarians and students that contributed to this study. Specially, we are grateful to Toni Richardson and Henry Marr (Intracellular Pathogens Research Laboratory College of Veterinary Medicine, North Carolina State University, NCSU) for technical assistance. Diana Andrea Murillo (Universitat Autònoma de Barcelona, UAB) for the assistance in sampling and Lourdes Alarcón (UAB) for the assistance with laboratory work.

Conflicts of Interest: The authors declare no conflict of interest. Edward B. Breitschwerdt is a founder, shareholder and chief scientific officer for Galaxy Diagnostics, Research Triangle Park, North Carolina, USA. Galaxy Diagnostics was not involved in any aspect of this study. The funders had no role in the design of the study; in the collection, analyses, or interpretation of data; in the writing of the manuscript, or in the decision to publish the results.

\author{
Abbreviations \\ BAPGM Bartonella Alpha-Proteobacteria Growth Medium \\ B.henselae Bartonellahenselae \\ ELISA Enzyme-linked immunosorbent assay \\ FIV Feline immunodeficiency virus \\ FeLV Feline leukemia virus \\ IFA Immunofluorescence antibody assay \\ IgG Immunoglobulin G \\ IgM Immunoglobulin $\mathrm{M}$ \\ k Cohen's Kappa value \\ NCSU North Carolina State University \\ OF Oral fluid \\ PBS Phosphate buffered saline
}




$\begin{array}{ll}\text { PCR } & \text { Polymerase chain reaction } \\ \text { SE } & \text { Standard error } \\ \text { SRID } & \text { Single radial immunodiffusion } \\ \text { TR-IFMAs } & \text { Time-resolved immunofluorometric assays }\end{array}$

\section{References}

1. Chomel, B.B.; Abbott, R.C.; Kasten, R.W.; Floyd-Hawkins, K.A.; Kass, P.H.; Glaser, C.A.; Pedersen, N.C.; Koehler, J.E. Bartonella henselae Prevalence in Domestic Cats in California: Risk Factors and Association between Bacteremia and Antibody Titers. J. Clin. Microbiol. 1995, 33, 2445-2450. [CrossRef] [PubMed]

2. La, V.D.; Clavel, B.; Lepetz, S.; Aboudharam, G.; Raoult, D.; Drancourt, M. Molecular detection of Bartonella henselae DNA in the dental pulp of 800-year-old French cats. Clin. Infect. Dis. 2004, 39, 1391-1394. [PubMed]

3. Breitschwerdt, E.B. Bartonellosis, One Health and all creatures great and small. Adv. Vet. Dermatol. 2017, 28, 96-e21. [CrossRef] [PubMed]

4. Álvarez-Fernández, A.; Breitschwerdt, E.B.; Solano-Gallego, L. Bartonella infections in cats and dogs including zoonotic aspects. Parasit. Vectors 2018, 11, 624. [CrossRef] [PubMed]

5. Caponetti, G.C.; Pantanowitz, L.; Marconi, S.; Havens, J.M.; Lamps, L.W.; Otis, C.N. Evaluation of immunohistochemistry in identifying Bartonella henselae in cat-scratch disease. Am. J. Clin. Pathol. 2009, 131, 250-256. [CrossRef]

6. Drummond, M.R.; Lania, B.G.; de Paiva Diniz, P.P.V.; Gilioli, R.; Demolin, D.M.R.; Scorpio, D.G.; Breitschwerdt, E.B.; Velho, P.E.N.F. Improvement of Bartonella henselae DNA Detection in Cat Blood Samples by Combining Molecular and Culture Methods. J. Clin. Microbiol. 2018, 56, e01732-17. [CrossRef]

7. Neupane, P.; Hegarty, B.C.; Henry, I.; Marr, S.; Maggi, R.G.; Birkenheuer, A.J.; Breitschwerdt, E.B. Evaluation of cell culture-grown Bartonella antigens in immunofluorescent antibody assays for the serological diagnosis of bartonellosis in dogs Background: Because of poor sensitivity and questionable specificity of immunofluorescent. J. Vet. Intern. Med. 2018, 32, $1958-1964$.

8. Drummond, M.R.; dos Santos, L.S.; da Silva, M.N.; de Almeida, A.R.; de Paiva Diniz, P.P.V.; Angerami, R.; Velho, P.E.N.F. False Negative Results in Bartonellosis Diagnosis. Vector-Borne Zoonotic Dis. 2019, 19, 453-454. [CrossRef]

9. Ficociello, J.; Bradbury, C.; Morris, A.; Lappin, M.R. Detection of Bartonella henselae IgM in Serum of Experimentally Infected and Naturally Exposed Cats. J. Vet. Intern. Med. 2011, 25, 1264-1269. [CrossRef]

10. Bradley, J.M.; Mascarelli, P.E.; Trull, C.L.; Maggi, R.G.; Breitschwerdt, E.B. Bartonella henselae Infections in an Owner and Two Papillon Dogs Exposed to Tropical Rat Mites (Ornithonyssus bacoti). Vector Borne Zoonotic Dis. 2014, 14, 703-709. [CrossRef]

11. Tabar, M.D.; Maggi, R.G.; Altet, L.; Vilafranca, M.; Francino, O.; Roura, X. Gammopathy in a Spanish dog infected with Bartonella henselae. J. Small Anim. Pract. 2011, 52, 209-212. [CrossRef] [PubMed]

12. Maurin, B.M.; Rolain, J.M.; Raoult, D. Comparison of In-House and Commercial Slides for Detection by Immunofluorescence of Immunoglobulins G and M against Bartonella henselae and Bartonella quintana. Clin. Diagn. Lab. Immunol. 2002, 9, 1004-1009. [CrossRef]

13. Barnes, A.; Bell, S.C.; Isherwood, D.R.; Bennett, M.; Carter, S.D. Evidence of Bartonella henselae infection in cats and dogs in the United Kingdom. Vet. Rec. 2000, 147, 673-677.

14. Neupane, P.; Sevala, S.; Balakrishnan, N.; Marr, H.; Wilson, J.; Maggi, R.; Birkenheuer, A.; Lappin, M.; Chomel, B.; Breitschwerdt, E.B. Validation of Bartonella henselae Western Immunoblotting for Serodiagnosis of Bartonelloses in Dogs. J. Clin. Microbiol. 2020, 58, e01335-19. [CrossRef]

15. Kordick, D.L.; Breitschwerdt, E.B. Relapsing bacteremia after blood transmission of Bartonella henselae to cats. Am. J. Vet. Res. 1997, 58, 492-497.

16. Pérez, C.; Maggi, R.G.; Diniz, P.P.V.P.; Breitschwerdt, E.B. Molecular and serological diagnosis of Bartonella infection in 61 dogs from the United States. J. Vet. Intern. Med. 2011, 25, 805-810. [CrossRef] [PubMed]

17. Pennisi, M.G.; La Camera, E.; Giacobbe, L.; Orlandella, B.M.; Lentini, V.; Zummo, S.; Fera, M.T. Molecular detection of Bartonella henselae and Bartonella clarridgeiae in clinical samples of pet cats from Southern Italy. Res. Vet. Sci. 2010, 88, 379-384. [CrossRef] [PubMed]

18. Morales, S.C.; Breitschwerdt, E.B.; Washabau, R.J.; Matise, I.; Maggi, R.G.; Duncan, A.W. Detection of Bartonella henselae DNA in two dogs with pyogranulomatous lymphadenitis. J. Am. Vet. Med. Assoc. 2007, 230, 681-685. [CrossRef]

19. Bai, Y.; Kosoy, M.Y.; Boonmar, S.; Sawatwong, P.; Sangmaneedet, S.; Peruski, L.F. Enrichment culture and molecular identification of diverse Bartonella species in stray dogs. Vet. Microbiol. 2010, 146, 314-319. [CrossRef]

20. Oskouizadeh, K.; Zahraei-Salehi, T.; Aledavood, S.J. Detection of Bartonella henselae in domestic cats' saliva. Iran. J. Microbiol. 2010, 2, 80-84.

21. Namekata, D.Y.; Kasten, R.W.; Boman, D.A.; Straub, M.H.; Siperstein-Cook, L.; Couvelaire, K.; Chomel, B.B. Oral shedding of Bartonella in cats: Correlation with bacteremia and seropositivity. Vet. Microbiol. 2010, 146, 371-375. [CrossRef] [PubMed]

22. Khurshid, Z.; Warsi, I.; Moin, S.F.; Slowey, P.D.; Latif, M.; Zohaib, S.; Zafar, M.S. Biochemical analysis of oral fluids for disease detection. In Advances in Clinical Chemistry; Academic Press Inc.: Cambridge, MA, USA, 2021; Volume 100, pp. $205-253$.

23. Miller, C.S.; Foley, J.D.; Bailey, A.L.; Campell, C.L.; Humphries, R.L.; Christodoulides, N.; Floriano, P.N.; Simmons, G.; Bhagwandin, B.; Jacobson, J.W.; et al. Current developments in salivary diagnostics. Biomark. Med. 2010, 4, 171-189. [CrossRef] [PubMed] 
24. Poli, A.; Giannelli, C.; Pistello, M.; Zaccaro, L.; Pieracci, D.; Bendinelli, M.; Malvaldi, G. Detection of salivary antibodies in cats infected with feline immunodeficiency virus. J. Clin. Microbiol. 1992, 30, 2038-2041. [CrossRef] [PubMed]

25. Westman, M.E.; Malik, R.; Hall, E.; Norris, J.M. Diagnosing feline immunodeficiency virus (FIV) infection in FIV-vaccinated and FIV-unvaccinated cats using saliva. Comp. Immunol. Microbiol. Infect. Dis. 2016, 46, 66-72. [CrossRef]

26. Hwang, J.; Gottdenker, N.; Oh, D.-H.; Lee, H.; Chun, M.-S. Infections by pathogens with different transmission modes in feral cats from urban and rural areas of Korea. J. Vet. Sci. 2017, 18, 541-545. [CrossRef]

27. Duncan, A.W.; Maggi, R.G.; Breitschwerdt, E.B. Bartonella DNA in dog saliva. Emerg. Infect. Dis. 2007, 13, 1948-1950. [CrossRef]

28. Alamán Valtierra, M.; Simón Valencia, C.; Fuertes Negro, H.; Unzueta Galarza, A.; Flores Somarriba, B.; Halaihel Kassab, N. Molecular Epidemiology of Bartonella henselae in Stray and Sheltered Cats of Zaragoza, Spain. Rev. Esp. Salud Publica 2016, 90, E5.

29. Harley, R.; Gruffydd-Jones, T.J.; Day, M.J. Determination of salivary and serum immunoglobulin concentrations in the cat. Vet. Immunol. Immunopathol. 1998, 65, 99-112. [CrossRef]

30. Hettegger, P.; Huber, J.; Paßecker, K.; Soldo, R.; Kegler, U.; Nöhammer, C.; Weinhäusel, A. High similarity of IgG antibody profiles in blood and saliva opens opportunities for saliva based serology. PLoS ONE 2019, 14, e0218456. [CrossRef]

31. Dowers, K.L.; Hawley, J.R.; Brewer, M.M.; Morris, A.K.; Radecki, S.V.; Lappin, M.R. Association of Bartonella species, feline calicivirus, and feline herpesvirus 1 infection with gingivostomatitis in cats. J. Feline Med. Surg. 2010, 12, 314-321. [CrossRef] [PubMed]

32. Quimby, J.M.; Elston, T.; Hawley, J.; Brewer, M.; Miller, A.; Lappin, M.R. Evaluation of the association of Bartonella species, feline herpesvirus 1 , feline calicivirus, feline leukemia virus and feline immunodeficiency virus with chronic feline gingivostomatitis. $J$. Feline Med. Surg. 2008, 10, 66-72. [CrossRef]

33. Harley, R.; Gruffydd-Jones, T.J.; Day, M.J. Salivary and serum immunoglobulin levels in cats with chronic gingivostomatitis. Vet. Rec. 2003, 152, 125-129. [CrossRef] [PubMed]

34. Cantos-Barreda, A.; Escribano, D.; Cerón, J.J.; Tecles, F.; Bernal, L.J.; Martínez-Subiela, S. Changes in the concentration of anti-Leishmania antibodies in saliva of dogs with clinical leishmaniosis after short-term treatment. Vet. Parasitol. 2018, 254, 135-141. [CrossRef]

35. Aylló, T.; Paulo, P.; Diniz, V.P.; Breitschwerdt, E.B.; Villaescusa, A.; Rodríguez-Franco, F.; Sainz, A. Vector-Borne Diseases in Client-Owned and Stray Cats from Madrid, Spain. Vector Borne Zoonotic Dis 2012, 12, 143-150. [CrossRef] [PubMed]

36. Pons, I.; Sanfeliu, I.; Quesada, M.; Anton, E.; Sampere, M.; Font, B.; Pla, J.; Segura, F. Prevalence of Bartonella henselae in cats in Catalonia, Spain. Am. J. Trop. Med. Hyg. 2005, 72, 453-457. [CrossRef] [PubMed]

37. Ravicini, S.; Pastor, J.; Hawley, J.; Brewer, M.; Castro-López, J.; Beall, M.; Lappin, M.R. Prevalence of selected infectious disease agents in stray cats in Catalonia, Spain. JFMS Open Rep. 2016, 2, 1-6. [CrossRef]

38. Solano-Gallego, L.; Hegarty, B.; Espada, Y.; Llull, J.; Breitschwerdt, E. Serological and molecular evidence of exposure to arthropod-borne organisms in cats from northeastern Spain. Vet. Microbiol. 2006, 118, 274-277. [CrossRef]

39. Yamamoto, K.; Chomel, B.B.; Kasten, R.W.; Hew, C.M.; Weber, D.K.; Lee, W.I.; Droz, S.; Koehler, J.E. Experimental infection of domestic cats with Bartonella koehlerae and comparison of protein and DNA profiles with those of other Bartonella species infecting felines. J. Clin. Microbiol. 2002, 40, 466-474. [CrossRef]

40. Baxarias, M.; Álvarez-Fernández, A.; Martínez-Orellana, P.; Montserrat-Sangrà, S.; Ordeix, L.; Rojas, A.; Nachum-Biala, Y.; Baneth, G.; Solano-Gallego, L. Does co-infection with vector-borne pathogens play a role in clinical canine leishmaniosis? Parasit. Vectors 2018, 11, 135. [CrossRef]

41. Canneti, B.; Cabo-López, I.; Puy-Núñez, A.; García García, J.C.; Cores, F.J.; Trigo, M.; Suárez-Gil, A.P.; Rodriguez-Regal, A. Neurological presentations of Bartonella henselae infection. Neurol. Sci. 2019, 40, 261-268. [CrossRef] [PubMed]

42. Diakou, A.; Di Cesare, A.; Accettura, P.M.; Barros, L.; Iorio, R.; Paoletti, B.; Frangipane di Regalbono, A.; Halos, L.; Beugnet, F.; Traversa, D. Intestinal parasites and vector-borne pathogens in stray and free-roaming cats living in continental and insular Greece. PLoS Negl. Trop. Dis. 2017, 11, e0005335. [CrossRef] [PubMed]

43. Morelli, S.; Crisi, P.E.; Di Cesare, A.; De Santis, F.; Barlaam, A.; Santoprete, G.; Parrinello, C.; Palermo, S.; Mancini, P.; Traversa, D. Exposure of client-owned cats to zoonotic vector-borne pathogens: Clinic-pathological alterations and infection risk analysis. Comp. Immunol. Microbiol. Infect. Dis. 2019, 66, 101344. [CrossRef] [PubMed] 